\title{
Potential of Natural Flocculant in Coagulation-Flocculation Wastewater Treatment Process
}

\author{
Badrus Zaman ${ }^{1}$ \\ ${ }^{1}$ Department of Environmental Engineering, Faculty of Engineering, Diponegoro University, Semarang - Indonesia
}

\begin{abstract}
Coagulation-flocculation process is one of the first step of wastewater treatment. Coagulant aid as flocculant material is an essential for it's treatment successfully as an important factor for the next step processes. Although, flocculant fron unnatural polymer have potentially to cause environmental contamination and may affect to human health due to its persistent in environment and difficulties to degraded. This paper examines some of the natural flocculants that have been developed and their potential used to wastewater treatment. A type of natural flocculant that is widely developed to treat wastewater is cassava starch. Plant seed extracts such as from Plantago ovata were able to remove turbidity was $>90 \%$ at pH 6-8. Flour of Moringa oleifera Lam seeds are used to treat various types of wastewater with the ability to remove color and turbidity was $>90 \%$. Tamarindus indica pods seed, able to remove golden yellow was $60 \%$ and was $25 \%$ for direct fast scarlet. The latest development was used durio seed to treat leachate that showed high potential as natural flocculant. Natural flocculant application for water and wastewater treatment is able to decrease of energy using to production and commercialization of it.
\end{abstract}

Keywords: Natural flocculant; Coagulation-flocculation; Wastewater treatment.

\section{Background}

Until now, wastewater treatment with coagulationflocculation system is still used as a common method for both large and small scale. This is done because it is an effective method as pre treatment to lighten the next treatment [1]. For that process, coagulant type and flocculant is one of important factor [2]. Inorganic or unnatural flocculant are widely used, but several cases are frequently reported (e.g. high concentration of coagulant and flocculant residual in water body that can be affected to human health and environmental contamination [3]. Therefore, natural plant and animalderived flocculant can provide a potential alternative for the treatment of wastewater. This paper was focused to discuss of natural flocculant from some plants.

\section{Natural flocculant from plant}

Basically coagulant/flocculant can be divided into chemical, grafted and natural [5]. It clasification as shown in fig 2. Some natural flocculant was derived from plant such as from Casava starch, Moringa oleifera seed, Plantago ovata seed, Cassia obtusifolia seed, Surjana seed, Maize seed, Tamarindus indica seed, Jatropha curcas seed, Strychnos potatorum nut, extracted pandan leaves Corn flour and durio starch etc.

General and purification process for production of natural flocculant by three steps i.e, Primary processing for removal undesired part from plant which this process was done with manual or mechanical pulverization. Next step is secondary processing (extraction) which this process used organic or alcohol solvent, water or salt solution for extraction. The third process is tertiary processing (Purification) by dialysis, lyophilization, ion-exchange or precipitation [6].

\subsection{Cassava starch}

Cassava starch is widely used as natural flocculant for wastewater treatment. Cassava starch or tapioca starch is produced primarily from the roots of the cassava plant. Simple starch extraction starting from selected cassava roots (age and root quality) and should be immediately after harvest (1-2 days from harvesting). Extraction steps process of cassava root start from peeling and washing (as preparation) then rasping pulping or grating (as rasping). After it, then purification process as starch washing. After dewatering and drying process then milling and packaging as finishing process. (www.cassavabiz.org/postharvest/ starch03. htm)

Pure starch typically white colour, insoluble in cold water or alcohol. It tasteless and odorless also. Pure starch molecul consists the linear and helical amylose molecule and the branched amylopectin molecule. It generally contain $20-25 \%$ amylose and $75-80 \%$ amylopectin depends on starch weight. Starch can be divided into native starch and modified starch [7]. Native starch usually used as natural flocculant.

Application of Cassava starch as natural flocculant using gelatinized starch compare with cassava starch

* Corresponding author: badruszaman2@gmail.com 
grafted polyDADMAC flocculants was investigated (fig. 1). The result shown the grafted samples is better to remove turbidity and TSS than using gelatinized starch. The gelatinized starch removal rate efficiency are $55-60 \%$ and grafted samples removal rate efficiency are 65-98 \% [8]. Starch-graft polyacrylic acid was used for wastewater treatment shown high efficieny to remove turbidity (until 97\%) [9]. Single PAM (Polyacrylamide) or starch mixture and sequential dual polymer injection was investigated for removal of turbidity and the result shown starch polymer injection resulted less efficiency than PAM when injection was applicated under aggressive flocculation (4min)/settling $(1 \mathrm{~min})$ conditions. When dual injection system of PAM and starch was apply, This condition shown significant reductions in PAM dosage and influence to floc size, floc specific gravity and flocculation kinetics [10].
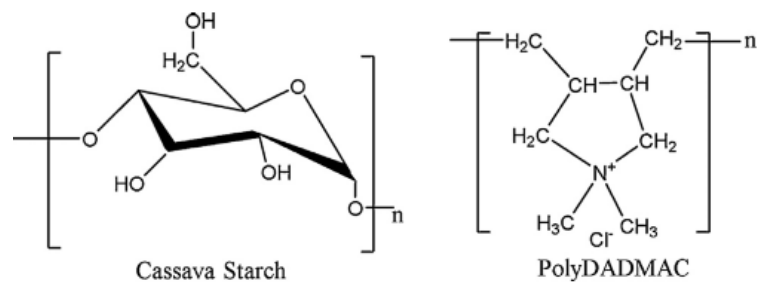

PolyDADMAC

Fig.1. Structure of Cassava Starch and PolyDADMAC [8].

\subsection{Plantago ovata}

Plantago ovata, known as one of a medicinal plant species which it native plant to Western Asia and Southern Asia lands [13]. Plantago ovata have many common names such as blond plantain [11] desert Indian wheat [12] blond psyllium and ispaghul. Plantago ovata commonly used as a source of psyllium and dietary fiber. It seed husks are indigestible and can used as a source of soluble fiber [14].

Study efficiency of Plantago ovata compare with starch extract as coagulant for removal of turbidity in water resulted P.ovata extract was higher capabilities in different $\mathrm{pH}$ values and turbidity levels than with starch extract [15]. Study of Plantago ovata seed extracts using distilled water, tap water, $\mathrm{NaCl}$ and ammonium acetate for turbidity removal as coagulant agents. It showed are less efficiency when in low turbidities, while distilled $\mathrm{NaCl}$ resulted highest coagulation activity in all initial turbidity concentrations (500, 150, and $50 \mathrm{NTU})$. This study showed distilled $\mathrm{NaCl}$ coagulant was able to remove efficiency from initial water turbidity until 98.2, 94.9, and $80.2 \%$, respectively [16].

\subsection{Moringa oleifera}

Moringa oleifera have structure deciduous tree, it can reach 10-12 m (32-40 ft) height with $45 \mathrm{~cm}(1.5 \mathrm{ft})$ trunk diameter. Hanging fruit with three-sided brown capsule of $20-45 \mathrm{~cm}$ size and holds dark brown, globular seeds with a diameter $1 \mathrm{~cm}$ approximately. The seeds will dispersed by wind and water which were have three whitish papery wings [17]. Lipid content in Moringa seed is dominated by oleic acid which $67.9 \%$. Others lipid species as shown in Table 1. Mature seeds ben oil contain high concentration of behenic acid.

Table 1. Lipid Content in Moringa oleifera [18]

\begin{tabular}{ll}
\hline Fatty Acids & Values (\%) \\
\hline Lauric acid (C12:0) & 0.1 \\
Myristic acid (C14:0) & 0.1 \\
Palmitic acid (C16:0) & 7.8 \\
Palmitoleic acid (C16:1) & 2.2 \\
Stearic acid (C18:0) & 7.6 \\
Oleic acid (C18:1) & 67.9 \\
Linoleic acid (C18:2) & 1.1 \\
Linolenic acid (C18:3) & 0.2 \\
Archidic acid (C20:0) & 4.0 \\
Eicosenoic acid (C20:1) & 1.5 \\
Behenic acid (C22:0) & 6.2 \\
Lignoceric acid (C24:0) & 1.3 \\
\hline
\end{tabular}

The seed moringa flour remaining after oil extraction can be used as a fertilizer or as a flocculant to removal water contaminant [19]. Moringa seed flour Which used into water treatment with flocculation process technology to produce potable water for domestic consumption [20-21]. Moringa seeds also can be used to absorb and netralize colloidal charges in turbid water to remove it as sludge. Moringa seed used for nontoxic and sustainable compared to other materials where drinking water was polluted [21] The main process of Moringa seed are primary, secondary and tertiary processes, but for natural flocculant which just primary process

Ionic nature of some coagulant agent when using moringa seed as coagulant/flocculant cause better for water treatment than for wastewater treatment. A significant correlation between the ionic strength in the solvent and the extraction yield, as well as the extract efficiency, also [22]. Flour Moringa oleifera Lam seeds are used to treat various types of wastewater with the ability to remove color and turbidity was $>90 \%$ [23] In recently research for water treatment by improve Moringa oleifera seed extract efficiency was mixed with iron oxide nanoparticles to create a magnetic coagulant and impacting to fast settling and easier separation of the flocs [24].

\subsection{Tamarindus indica}

Tamarind (Tamarindus indica) is a leguminous tree in the family Fabaceae indigenous to tropical Africa. Pod-like fruit that produce by tamarind tree can be used for cuisines because contains an edible pulp. It can be uses for metal polis and traditional mediceine. Tamarind tree sometimes used for wood working. The tamarind seed also can be used as natural coagulant/flocculant [25]. Oil can extract from tamarind seed. Many uses of tamarind seed cause tamarind tree found in tropical and subtropical land. 
Turbidity removal efficiency using Tamarindus indica fruit crude pulp extract (CPE) showed ranging from 64 to $99 \%$ [26]. The powder extracted from mature-dried Tamarindus indica seeds used for the turbidity reduction of polluted river water resulted maximum $91.16 \%$ turbidity reduction efficiency when aided with $0.5 \%$ PAM (Polyacrylamide) [27]. Removal turbidity from textile wastewater founded that natural coagulant from Tamarind worked better which the highest turbidity reduction efficiency of about $78 \%$ [28], but maximum removal efficiency in Moringa Oleifera than Tamarindus Indica on the major pollutants of concerned in waste water treatment, such as pH, Turbidity, TS, Total Dissolved and Suspended Solid [29-30]. That study indicated Moringa Oleifera seed powder is better influence in removal of physicochemical parameters, whereas Tamarindus Indica seed powder is better in removal of heavy metals from waste water when compare to Moringa Oleifera Seed Powder [29].

\subsection{Durio}

Durio are known as durian. Durio in Southeast Asia called King of Fruits with strong odour. It can grow more than 30 centimetres long and 15 centimetres diameter with 1 to 3 kilograms weighs. The colour of durio husk is green to brown with flesh pale colour is yellow to red depend on it species and it seeds when cooked can be used for cuisine (31).

From proximate analysis showed durian seed flour (whole) contained water, protein, ash, fat, crude fibre cabohydrate and total dietary fibre are $6.5 \%, 6.0 \%$, $3.1 \%, 0.4 \%, 10.1 \%, 73.9 \%$ and $52.9 \%$, respectively. While, for dehulled durian seed are $6.6 \%, 7.6 \%, 3.8 \%$, $0.4 \%, 4.8 \%$ and $76.8 \%$ and $7.7 \%$, respectively [32].

The study of Durio seeds as natural flocculant for landfill leachate treatment using Jar test results that optimum $\mathrm{pH}$ and dosages values for DSS flocculant were $\mathrm{pH} 6$ and $4000 \mathrm{mg} / \mathrm{L}$ with removal of true colour and turbidity were $34 \%$ and $36.9 \%$ respectively [33]. Newest study is to know the behavior and mechanisms of cross-linked Durio zibethinus seed starch flocculants for landfill leachate treatment. The application of crosslinking modification for Durio zibethinus seed waste starch flocculants showed significant removal efficiency improvement. The addition of it flocculants was able to increased colour, COD, suspended solid and turbidity removal efficiency [34].

\section{Challanges of natural flocculant}

Several studies have been done in order to develop greener alternatives to the conventional flocculant. It investigation resulted that natural flocculant promising potential for many paramaters efficiency. The main advantages of natural flocculant are their renewability, biodegradability, nontoxicity and relative costeffectiveness [35], but for development in the future constrained by some challanges i.e, Natural flocculent tend to have shorter live which caused by biodegradability of active component, floc will loose strength and stability with time also [5]. The biodegradation can caused by contain of hydrolysable groups along with the main chain in the most biodegradable natural and biopolymers [36], some of the anionic bio-flocculants are moderately effective and only can be utilised as flocculant which required cationic for charge neutralisation before bio flocculant [5], but natural flocculant can reducing turbidity but still less to know flocs formed characteristics and properties.

Beside that, the problem for use of crude extracts is organic matters. It can able to leaching into water product where frequently as total organic carbon, dissolved organic carbon and others.

Although some challanges and limitation for develop natural flocculant, some solution can be applicated i.e., Increasing knowledge and processes of coagulant/flocculant theory such as floc structure, floc strength, and compactness [37]. That can be done with various microscopy imaging techniques such as Scanning Electron Microscope (SEM), Transmission Electron Microscopy, Fourier Transform Infra Red (FTIR) which could provide surface and structure characteristics were to improve analysis [4]. Grafted natural flocculant with chemical polymer which experiment indicated that exhibited not only a highly flocculation effect on the water samples via charge attraction but also an effective antibacterial property [38], blending beetwen Natural flocculant and chemical coagulant can also as alternative method [4], use of active agents could be solve the problem of organic and anorganic which leaching to treated water [39-40].

The other challanges is not many can be reached to commercialization of product. The four main factors limitation for the commercialization of natural coagulants product are financial, research and development and market awareness (Fig. 2) [4;41]. Some Solution is needed to comprehensive cooperation for successfully commercialization of natural flocculant product but may still needed a long time to success (Fig.2) [4].

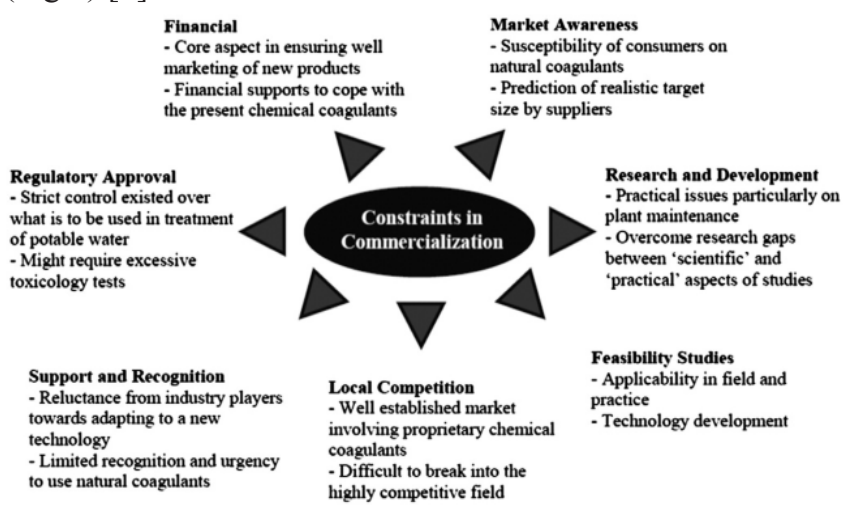

Fig. 2. Some factor were limitation for commercialization of natural coagulants [4]. 


\section{Conclusions}

From this analysis can be concluded as follows :

1. Some natural flocculant from plant was promising for used in wastewater and water treatment with different performance, for example is Moringa Oleifera seed powder is better influence in removal of physicochemical parameters, whereas Tamarindus Indica seed powder is better in removal

\section{References}

1. Verma, $M$ and Kumar, R.N. 2016. Can coagulation-flocculation be an effective pretreatment option for landfill Leachate and municipal wastewater co-treatment?. Perspectives in Sci8, 492-494. .(2016) www.elsevier.com/pisc

2. Liu, X., Li, X.M., Yang, Q., Yue, X., Shen, T. T. , Zheng, W., Luo, K.,Sun, Y.H., Zeng, G.M., Landfill leachate pretreatment by coagulationflocculation process using iron based coagulants: optimization by response surface methodology. Chem. Eng. J.202, 39-51.(2012).

3. I. Bodlund, A.R. Pavankumar, R. Chelliah, S. Kasi, K. Sankaran, G.K. Rajarao, Coagulant proteins identified in Mustard: a potential water treatment agent, Int. J. Environ. Sci. Technol. 11. 873880.(2014)

4. Choy, S.,Y., Prasad, K.,M.,N., Wu, T., Y., Raghunandan, M., E., Ramanan, R., N. Utilization of plant-based natural coagulants as future alternatives towards sustainable water clarification. J. Of. Env. Sci. 21782189.(2014).www.journals.elsevier.com/journal-ofenvironmental-sciences

5. Lee, C., S., Robinson, J., Chong, M.,F. 2014. A review on application of flocculants in wastewater treatment. Proc. Safety and Env. Prot. 92489 508.(2014). www.elsevier.com/locate/psep

6. Yin, C.Y., Emerging usage of plant-based coagulants for water and wastewater treatment. Process Biochem. 45, 1437-1444.(2010).

7. Brown, W. H.; Poon, T. Introduction to organic chemistry (3rd ed.). Wiley. (2005). ISBN 0-47144451-0.

8. M.A.A. Razali, A. Ariffin. 2015. Focculant Based on Cassava Starch Grafted Polydiallyl Dimethyl Ammonium Chloride: Flocculation Behavior and Mechanism. Appl. Surf. Sci.351. 89-94. (2015). www.elsevier.com/locate/apsusc

9. Du, Q., Wang, Y., Li, A., Yang, H.Scale-inhibition and flocculation dual-functionality of poly(acrylicacid) grafted starch.J. of Env. Man. 210. 273-279 (2018)

10. Lapointe, M., Barbeau. B. 2017. Dual starchepolyacrylamide polymer system for improved flocculation .Water Res. 124. 202-209. (2017). www.elsevier.com/locate/watres of heavy metals from waste water when compare to Moringa Oleifera Seed Powder

2. Based on Challanges and limitation for developed natural flocculant was have some solution for applicated in method of preparation and maked of natural flocculant.

3. Comprehensive cooperation needed for successfully commercialization of natural flocculant was needed as solution of some it contraints

11. BSBI List . Botanical Society of Britain and Ireland. Archived from the original (xls) on 2015-01-25. Retrieved .10-17. (2014)

12. USDA PLANTS, retrieved 10 June 2016

13. USDA GRIN Taxonomy, retrieved 10 June 2016. http://www.madrean.org/ symbflora/taxa/index.php?taxauthid $=1 \& \operatorname{taxon}=1597$ $\& \mathrm{cl}=2720$.

14. Fernández-Bañares F, Hinojosa J, SánchezLombraña JL, Navarro E, Martínez-Salmerón JF, García-Pugés A, González-Huix F, Riera J, González-Lara V, Domínguez-Abascal F, Giné JJ, Moles J, Gomollón F, Gassull MA.Randomized clinical trial of Plantago ovata seeds (dietary fiber) as compared with mesalamine in maintaining remission in ulcerative colitis. Spanish Group for the Study of Crohn's Disease and Ulcerative Colitis (GETECCU). Am. J. Gastroenterol. 94 (2): $427-$ 33. (1999) doi:10.1016/s0002-9270(98) 007539. PMID 1002264

15. Shahriari, T., Nabi B., G., Shahriari, Sh. Evaluating the Efficiency of Plantago Ovata and Starch in Water turbidity removal. Int. J. Environ. Res., 6(1):259-264. (2012).

16. Dhivya,S., S. T. Ramesh, R. Gandhimathi, P. V. Nidheesh. Performance of Natural Coagulant Extracted from Plantago ovata Seed for the Treatment of Turbid Water. Water Air and Soil Pollution 228(11). (2017).

17. Parotta, John A. (1993). Moringa oleifera Lam. Reseda, horseradish tree. Moringaceae. Horseradish tree family. USDA Forest Service, International Institute of Tropical Forestry. Retrieved .1120.(2013).

18. Abdulkarim, S.,M., Long, K., Lai., O., M., Muhammad, S.,K.,S., Ghazali,.H.,M.,. Some physico-chemical properties of Moringa oleifera seed oil extracted using solvent and aqueous enzymatic methods. Food Chemistry 93(2):253$263 \cdot(2005)$.

19. Lea, M., Bioremediation of Turbid Surface Water Using Seed Extract from Moringa oleifera Lam. (Drumstick) Tree. Current Protocols in Microbiology. doi: $10.1002 / 9780471729259 . \mathrm{mc} 01 \mathrm{~g} 02 \mathrm{~s} 16$. ISBN 0471729256.

20. Ndabigengesere, Anselme; Narasiah, K.Subba; Talbot, Brian G. Active agents and mechanism of 
coagulation of turbid waters using Moringa oleifera. Water Research. 29 (2). 703-710.(1995). doi:10.1016/0043-1354(94)00161-Y.

21. Hellsing, Maja S.; Kwaambwa, Habauka M.; Nermark, Fiona M.; Nkoane, Bonang B.M.; Jackson, Andrew J.; Wasbrough, Matthew J.; Berts, Ida; Porcar, Lionel; Rennie, Adrian R. Structure of flocs of latex particles formed by addition of protein from Moringa seeds. Colloids and Surfaces A: Physicochemical and Engineering Aspects. 460. (2013). 460-467. doi: $10.1016 /$ j.colsurfa.2013.11. 038.

22. Villasenor-Basulto, D.,L., Astudillo-Sanchez, P., D., Real-Olvera, J., D., Bandala, E., R. Wastewater treatment using Moringa oleifera Lam seeds: A review. Journal of Water Process Engineering 23 .151-164.(2018).

23. Idris, J., Md Som, A., Musa, M., Ku Hamid, K.H., Husen, R., Muhd Rodhi, M.N., 2013. Dragon fruit foliage plant-based coagulant for treatment of concentrated latex effluent: comparison of treatment with ferric sulfate. J.Chem.http://dx.doi.org/ $10.1155 / 2013 / 230860$.

24. T.R. Santos, M.F. Silva, L. Nishi, A.M. Vieira, M.R. Klein, M.B. Andrade,M.F. Vieira, R. Bergamasco, Development of a magnetic coagulant based on Moringa oleifera seed extract for water treatment, Env. Sci. Pollut. Res. 1-9. (2016)

25. "Tamarind" https://en.wikipedia.org/wiki/ Tamarind

26. Sa'id, S., Mohammed, K., Adie, D. B., Okuofu, C. A. Turbidity Removal From Surface Water Using Tamarindus indica Crude Pulp Extract. Bayero Journal of Pure and Applied Sciences, 9(1): 236 240. (2016).

27. Rahman, M.,M., Sarker, P., Saha, B., Jakarin, N., Shammi, M., Uddin, M.,K., Sikder, Md., T. Removal of Turbidity from the River Water using Tamarindus indica and Litchi chinensis Seeds as Natural Coagulant. Intern. J. of Env. Prot. and Policy 2015; 3(2-1): 19-26. (2015). www.science publishinggroup.com/j/ijepp

28. Kumawat, N., Koul., N., Indrekar, J., Payghan, S., Treatment Of Textile Effluent By Using Natural Coagulants. 7th International Conference on Recent Trenda in Engineering, Science \& Management. www. conferenceworld.in. (2017). ISBN: 978-9386171-12-2.

29. Prasad, S.,V., Rao, B., S. 2016. Influence of PlantBased Coagulants in Waste Water Treatment. Int.J. of Latest Tech. in Eng. Man. \& App. Sc. 5(3): 4548.

30. Ramesh, S., Mekala,L. 2018. Treatment Of Textile Waste Water Using Moringa Oleifera and Tamarindus Indica. Intern. Research J. of Eng. and Tech. (IRJET) 05(03). (2018)

31. "Durio zibethinus" https://en.wikipedia.org/ wiki/Durio zibethinus

32. Amin, A., M., Arshad, R. Proximate composition and pasting properties of durian (Durio zibethinus) seed flour. Int. J. of Postharvest Tech. and Innov. 1(4) (2009). doi: 10.1504/IJPTI.2009.030685
33. Zamri' M., F., M., A., Suja, F., Yusoff, M., S., Aziz, H., A., Bahru, R. The comparison of Durio Zibethinus seed starch extraction for landfill leachate treatment. Mat.Research Exp.5(7).(2018)

34. Yusoff, M., S., Aziz, H., A., Zamri, M., F., M., A., Abdullah, A., Z., Basri, N., E., A., Suja, F. 2018. Floc behavior and removal mechanisms of crosslinked Durio zibethinus seed starch as a natural flocculant for landfill leachate coagulationflocculation treatment. Waste Management. 74. 362-372. (2018) www.elsevier.com/ locate/wasman.

35. Sillanp, M., Ncibi, M., C., Matilainen, A., Vepsalainen, M. Removal of natural organic matter in drinking water treatment by coagulation: A comprehensive review. Chemosphere 190 54-71. (2018) . www.elsevier.com/locate/chemosphere.

36. Singh, R.P., Karmakar, G.P., Rath, S.K., Karmakar, N.C., Pandey, S.R., Tripathy, T., Panda, J., Kanan, K., Jain, S.K., Lan, N.T., Biodegradable drag reducing agents and flocculants based on polysaccharides: materials and applications. Polym. Eng. Sci.(2000).

37. Li, T., Zhu, Z., Wang, D.S., Yao, C.H., Tang, H.X., Characterization of floc size, strength and structure under various coagulation mechanisms. Powder Technol. 168 (2), 104-110. (2006).

38. Huang, M., Liu, Z., Li, A., Yang, H. 2017. Dual functionality of a graft starch flocculant: Flocculation and antibacterial performance. Journal of Environmental Management 196 63-71. (2017). www.elsevier.com/locate/jenvman

39. Ghebremichael, K., Overcoming the drawbacks of natural coagulants for drinking water treatment. Water Sci. Technol.Water Supply 7 (4), 87 93.(2007).

40. Sathiyabama, M., Purification of a coagulant protein from seeds of Moringa concanensis. Water Sci. Technol. Water Supply 12 (3), 329-333. (2012).

41. Sutherland, J., Folklard, G., Poirier, Y., Moringa oleifera. The constraints to commercialization. International Workshop: 29th October-2nd November, Dar es Salaam, Tanzania, (2001). 